10 Isles CG, Brown JJ, Cumming AMM, et al. Excess smoking in malignant phase hypertension. BrMed f 1979;i:579-81.

11 Brown JJ, Lever AF, Robertson JIS. Blood pressure and sodium: a personal view. In: Genest J, Kuchel O, Hamet P, Cantin M, eds. Hypertension: physiopathology and treatment. 2nd ed. New York: McGraw-Hill, 1983:632-45.

12 Weir RJ, Briggs E, Mack A, Naismith L, Taylor L, Wilson E. Blood pressure in women taking oral contraceptives. BrMed J 1974;i:533-5.

13 Gavras $\mathrm{H}$, Oliver N, Aitchison J, et al. Abnormalities of coagulation and the development of malignant phase hypertension. Kidney Int 1975;8:S252-61.

14 Isles CG, Lowe GDO, Rankin BM, et al. Abnormal haemostasis and blood viscosity in malignant hypertension: cause or effect. Thromb Haemost 1984;52:253-5.

15 Vessey MP, Doll R. Investigation of relation between use of oral contraceptives and thromboembolic disease. Br Med J 1968;ii:199-205.
16 Collaborative group for the study of stroke in young women. Oral contraceptive and increased risk of cerebral ischaemia or thrombosis. N Engl f Med 1973;288:871-8.

17 Jick H, Dinam B, Herman R, Rothman KJ. Myocardial infarction and other vascular diseases in young women. Role of oestrogens and other factors. JAMA 1978;240:2548-54.

18 Golbus SM, Swerdlin AR, Mitas JA, Rowley WR, James DR. Renal artery thrombosis in a young woman taking oral contraceptives. Ann Intem Med 1979;90:939-40.

19 Boyd WN, Burden RP, Aber GM. Intrarenal vascular changes in patients receiving oestrogen containing compounds-a clinical, histological and angiographic study. $Q$ f Med 1975;44: 415-31.

20 Isles CG, Lim KG, Boulton-Jones M, et al. Factors influencing mortality in malignant hypertension. Joumal of Hypertension 1985;3(suppl 3):S405-7.

(Accepied 13 February 1987)

\title{
Childhood asthma in adult life: a further study at 28 years of age
}

\author{
W J W KELLY, I HUDSON, P D PHELAN, M C F PAIN, A OLINSKY
}

\begin{abstract}
A group of 323 subjects who had wheezed in childhood and 48 control subjects of the same age were studied prospectively from 7 to 28 years of age. A classification system based on wheezing frequency was found to correlate well with clinical and spirometric features of airway obstruction. The amount of wheezing in early adolescence seemed to be a guide for severity in later life with $73 \%$ of those with few symptoms at 14 continuing to have little or no asthma at 28 years. Similarly $68 \%$ of those with frequent wheezing at 14 still suffered from recurrent asthma at 28 years. Most subjects with frequent wheezing at 21 continued to have comparable asthma at 28 years. Of those with infrequent wheezing at $21,44 \%$ had worsened at 28 years. Women fared better than men between 21 and 28 with $19 \%$ having worse symptoms compared with $28 \%$ of men. Treatment at all ages was generally inadequate. The number of smokers among those with asthma was of concern.
\end{abstract}

\section{Introduction}

This paper reports the progress of a group of asthmatics who have been studied for 21 years from the age of 7 . The study of the clinical course of any chronic illness is best achieved by the long term follow up of a representative matched group of subjects sampled to cover the full range of the disease. The course of asthma can be documented only in this way, but few studies have been reported. These have either been hospital or clinic based, ${ }^{1-3}$ with the potential for biased selection, or community based, with the problems arising from movement in and out of the community and from the heterogeneity of ages studied..$^{46}$ Unfortunately, studies on the epidemiology of asthma have generally used different definitions of the disease, making direct comparison between them difficult. ${ }^{1245}$

$\mathrm{McNicol}$ and Williams ${ }^{7.9}$ and Martin et $a^{10-14}$ described a com-

Departments of Thoracic Medicine, Royal Children's and Royal Melbourne Hospitals, Melbourne, Australia

W J W KELLY, FRACP, research fellow

I HUDSON, MSC, PHD, biostatistician, Royal Children's Hospital

P D PHELAN, FRACP, professor of paediatrics, University of Melbourne

M C F PAIN, FRACP, director, department of thoracic medicine, Royal Melbourne Hospital

A OLINSKY, FRACP, director, department of thoracic medicine, Royal Children's Hospital

Correspondence to: Dr W J W Kelly, Department of Thoracic Medicine, Royal Children's Hospital, Parkville, Victoria, Australia, 3052. munity based group of children with asthma who had been randomly selected from one age cohort and studied to the ages of 14 and 21 respectively. This paper describes the state of their asthma at 28 years and the course of their illness from 21 to 28.

\section{Subjects and methods}

In 1964,401 children were randomly selected from roughly 30000 7 year olds living in Melbourne, Victoria. They comprised 106 children who had never wheezed and 295 who had been identified by questionnaire and interview as having wheezing of variable severity. These children were studied at 7 years of age and were recalled at the age of 10 for further investigation. At that stage a further $\mathbf{8 3}$ children from the same age cohort but with more severe asthma were added to the original study group. The subjects were not part of a clinic based population and the investigators were not responsible for their management: one of the conditions laid down by the local medical association for its cooperation was that no advice about management would be offered to the subjects or their families.

When the subjects had reached the age of 14 they were recalled and examined; $329(82 \%)$ of the original group were seen (a slightly higher proportion of children with asthma attended than controls) together with 68 of the additional 83 children with asthma. Four grades of severity were defined at that time ${ }^{7}$ : class A-children with no more than five episodes of wheezing up to 14 years of age; class $B$-children with more than five episodes of wheezing but none in the 12 months before examination; class $\mathrm{C}$-children with a continuing history of asthma over several years who had continued to wheeze in the previous 12 months; class D-children with very frequent or unremitting asthma.

The group was restudied at the age of 21 in 1978-9, when 408 subjects were contacted. A full review was performed on 342 , and questionnaire data only were obtained from a further 66 . A new severity classification was defined as definitions used at 14 years could only be used at that age ${ }^{10}$ : class W-subjects who had not wheezed for three or more years before the age of 21 ; class X-subjects who had wheezed in the previous three years but not in the previous three months; class $\mathrm{Y}$-subjects who had wheezed in the previous three months but whose frequency of wheezing was less than once a week; class Z-subjects who had wheezed more frequently than once a week in the previous three months.

In the 12 months from March 1985, 371 of the original group were restudied ( 323 with wheezing in childhood and 48 controls). This comprised a full review in $286(77 \%)$ and a postal questionnaire in $85(23 \%)$. The full study consisted of a questionnaire, physical examination, skin testing with five common allergens, and respiratory function tests. Blood was taken for eosinophil counts and IgE concentration. The questionnaire and the definitions used in the physical examination at 21 were followed as closely as possible at the 28 year review. The class definitions developed at 21 were used again at 28 with the exception that the class names were changed: class $W$ was renamed class $S, X$ became $T, Y$ became $U$, and $Z$ became $V$. The same investigator performed all the interviews, examinations, and tests.

The dynamic lung volumes were measured using an 8 litre, dry rolling seal spirometer (Morgan TLCtest, P K Morgan, Chatham, Kent) and corrected 
to body temperature and pressure, saturated. Standard prediction equations were used for both subjects with asthma and controls. ${ }^{1516}$

Each subject answered detailed questions concerning treatment, and an attempt was made to assess the level of treatment each subject with asthma was receiving and to grade them according to their class. Adequate treatment for class $S$ was no treatment; for subjects in class $T$ bronchodilators that were used in acute attacks only; for class $U$ regular bronchodilators alone, regular sodium cromoglycate with intermittent bronchodilators, or inhaled corticosteroids with regular bronchodilators; and for class $\mathrm{V}$ regular bronchodilators alone or with regular inhaled corticosteroids or sodium cromoglycate. Oral corticosteroids may have been used for either short or prolonged periods. This classification was very similar to that used at 21 years to allow comparison of treatment at both ages. ${ }^{11}$

Statistical analysis was done by the SPSSX statistical computing package on a Vax 11/780 computer at the Computer Services Centre, University of Melbourne, and the StatView Statistics Utility on an Apple Macintosh personal computer. Groups were compared using the $\chi^{2}$ test or Student's $t$ test as appropriate.

\section{Results}

The numbers of subjects seen at both 21 and 28 years and their grades are given in table I. A total of 408 subjects had been seen at 21 years, of whom 362 were seen at 28 years. Nine subjects seen at 14 years but not at 21 were studied also: they have been included in the description of the group at 28, but have been omitted from any comparisons of the group at 28 with that at 21 . The overall recall of the 21 year group at 28 was $89 \%$ with similar recall for each of the 21 year groups; $77 \%$ of those seen at 10 were seen at 28 years. Seven of the controls seen at 21 gave a history of wheezing before the 28 year study and were placed in the appropriate group.

The sex ratio in each group at 14,21, and 28 years is shown in table II. The marked imbalance towards males in the 14 year classes $C$ and $D$ lessened over the intervening years. At the start of the study, more boys with severe asthma were included, reflecting the community prevalence of the disease at those ages, and hence, there were more males in the study.

Progress from 21 to 28 years according to sex was as follows: among the men $59(28 \%)$ moved to a worse class, $36(17 \%)$ to a better class, and in 116 $(55 \%)$ there was no change. Among the women the figures were $28(19 \%), 38$ (25\%), and $85(56 \%)$ respectively. While the majority of both sexes had not altered the severity of their asthma, significantly more men than women had moved to more severe groups $(p<0.05)$.

The occurrence in the three years before the interview of hay fever, eczema, and urticaria of any severity are shown in table III. Additionally, the presence of episodes of productive cough in the previous 12 months are shown. The presence of urticaria was not a distinguishing feature in any of the classes, unlike hay fever for groups $T, U$, and V and eczema for group V. A productive cough was significantly more common in groups $\mathrm{U}$ and $\mathrm{V}$.

Table IV shows the incidence of significant abnormal findings on physical examination. Abnormal nasal mucosa refers to the presence of either pale oedematous mucosa or hyperaemic mucosa. Only in the most severe class, $\mathrm{V}$, were the presence of clinical chest hyperexpansion and wheezing on auscultation more common than in the control group. Other abnormalities of chest shape such as pigeon chest, funnel chest, and Harrison's sulci did not differ significantly between the groups. Crackles on auscultation were

TABLE I-Numbers of subjects seen at both 21 and 28 years. Figures in parentheses after 21 year numbers represent percentages of each 21 year old class seen at 28

\begin{tabular}{lllllll}
\hline & & \multicolumn{5}{c}{ Class } \\
\cline { 3 - 6 } & Control & W/S & $\mathrm{X} / \mathrm{T}$ & $\mathrm{Y} / \mathrm{U}$ & $\mathrm{Z} / \mathrm{Y}$ & Total \\
\hline 21 Years & $55(89)$ & $100(88)$ & $62(91)$ & $79(90)$ & $66(86)$ & 362 \\
28 Years & 48 & 105 & 67 & 71 & 80 & 371 \\
\hline
\end{tabular}

Nine subjects who were last seen at 14 years were seen again at 28 .

TABLE II-Male:female ratio of classes seen at various ages

\begin{tabular}{lccccc}
\hline & & \multicolumn{5}{c}{ Class } \\
\cline { 3 - 6 } & Controls & A/W/S & B/X/T & C/Y/U & D/Z/V \\
\hline 14 Years & $49: 51$ & $42: 58$ & $62: 38$ & $68: 32$ & $80: 20$ \\
21 Years & $50: 50$ & $64: 36$ & $65: 35$ & $60: 40$ & $60: 40$ \\
28 Years & $50: 50$ & $61: 39$ & $57: 43$ & $56: 44$ & $65: 35$ \\
\hline
\end{tabular}

TABLE III-Presence of associated conditions. Figures represent numbers in each group (percentage in parentheses)

\begin{tabular}{|c|c|c|c|c|c|}
\hline & \multirow[b]{2}{*}{ Controls } & \multicolumn{4}{|c|}{ - Class } \\
\hline & & $S$ & $\mathbf{T}$ & $\mathbf{U}$ & $\mathrm{V}$ \\
\hline $\begin{array}{l}\text { Hay fever } \\
\text { p value } \\
\text { Eczema } \\
\text { p value } \\
\text { Urticaria } \\
\text { p value } \\
\text { Productive cough } \\
\text { p value }\end{array}$ & $\begin{array}{l}16(33) \\
6(13) \\
4(8) \\
4(8)\end{array}$ & $\begin{array}{l}49(47) \\
\text { NS } \\
17(16) \\
\text { NS } \\
13(12) \\
\text { NS } \\
4(4) \\
\text { NS }\end{array}$ & $\begin{array}{c}37(55) \\
\star \\
15(22) \\
\text { NS } \\
10(15) \\
\text { NS } \\
9(13) \\
\text { NS }\end{array}$ & $\begin{array}{c}42(59) \\
\star \star \\
17(24) \\
\text { NS } \\
6(8) \\
\text { NS } \\
31(44) \\
\star \star \star\end{array}$ & $\begin{array}{c}51(64) \\
\star \star \star \\
33(41) \\
\star \star \star \\
10(13) \\
N S \\
24(30) \\
\star \star\end{array}$ \\
\hline Total number of subjects & 48 & 105 & 67 & 71 & 80 \\
\hline
\end{tabular}

${ }^{\star}=\mathrm{p}<0.05 ;{ }^{\star \star}=\mathrm{p}<0.01 ;{ }^{\star \star \star}=\mathrm{p}<0.001$.

TABLE IV-Features of physical examination. Figures represent numbers in each group (percentage in parentheses)

\begin{tabular}{|c|c|c|c|c|c|}
\hline & \multirow[b]{2}{*}{ Controls } & \multicolumn{4}{|c|}{ Class } \\
\hline & & $\mathbf{S}$ & $\mathbf{T}$ & $\mathrm{U}$ & V \\
\hline $\begin{array}{l}\text { Abnormal nasal mucosa } \\
\text { p value }\end{array}$ & $4(8)$ & $\begin{array}{l}9(8) \\
\text { NS }\end{array}$ & $\begin{array}{c}12(18) \\
\text { NS }\end{array}$ & $\underset{\star \star \star}{28(39)}$ & $\underset{\star \star \star \star}{33(41)}$ \\
\hline $\begin{array}{l}\text { Cough at interview } \\
\text { p value }\end{array}$ & $4(8)$ & $\begin{array}{l}10(9) \\
\text { NS }\end{array}$ & $\begin{array}{l}8(12) \\
\text { NS }\end{array}$ & $16(23)$ & $\underset{\star \star}{26(33)}$ \\
\hline $\begin{array}{l}\text { Barrel chest } \\
\text { p value }\end{array}$ & $2(4)$ & $\begin{array}{l}0(0) \\
\text { NS }\end{array}$ & $\begin{array}{l}5(8) \\
\mathrm{NS}\end{array}$ & $\begin{array}{l}3(4) \\
\text { NS }\end{array}$ & $18(23)$ \\
\hline $\begin{array}{l}\text { Wheeze at rest } \\
\text { p value }\end{array}$ & $4(8)$ & $\begin{array}{l}0(0) \\
N S\end{array}$ & $\begin{array}{l}9(13) \\
\text { NS }\end{array}$ & $11(15)$ & $30(38)$ \\
\hline $\begin{array}{l}\text { Wheeze after coughing } \\
\text { p value }\end{array}$ & $2(4)$ & $\begin{array}{l}0(0) \\
\text { NS }\end{array}$ & $\begin{array}{l}6(9) \\
\mathrm{NS}\end{array}$ & $\begin{array}{l}1(2) \\
\mathrm{NS}\end{array}$ & $\underset{\star \star \star}{27(34)}$ \\
\hline Total number of subjects & 48 & 105 & 67 & 71 & 80 \\
\hline
\end{tabular}

$\star=p<0.05 ; \star \star *=p<0.01 ; \star \star \star * p<0.001$.

present in $3.5 \%$ of the total group, with no class predominating. Mean blood pressures for the group were $122 / 76 \mathrm{~mm} \mathrm{Hg}$ (SD 15/9) with no appreciable difference between the various classes. A breakdown of heights and weights for the various classes showed no difference between the controls and any of the subjects with asthma.

The results of spirometry for each class are shown in table V. The vital capacity was similar in all groups, but the forced expiratory volume in one second, forced expiratory volume in one second/vital capacity, and the forced expiratory flow between $25 \%$ and $75 \%$ of the forced vital capacity were all significantly lower in classes $\mathrm{T}, \mathrm{U}$, and $\mathrm{V}$ than in the control group.

There was no difference in either current smoking habits or history expressed in pack years between the controls and any of the study groups. Table VI shows the current smoking habits of the groups.

Subjects' data were analysed for adequacy of treatment at 21 and 28 years. At 21 those subjects who received adequate treatment were as follows: class $\mathrm{X} / \mathrm{T} 11$ ( $18 \%$ of the total of original subjects in the group), class $\mathrm{Y} / \mathrm{U}$ nine $(11 \%)$, and class $\mathrm{Z} / \mathrm{V} 26(39 \%)$; at age 28 the numbers were class X/T 17 (25\%), Y/U nine (13\%), and Z/V $56(70 \%)$. The adequacy of treatment was not appreciably different at 21 and 28 .

The 14 and 28 year old classes of those subjects seen at both ages are shown in table VII. The different classes cannot be directly compared but general inferences can be drawn. Forty four subjects who were not seen at 14 but who participated in other phases of the study are included in this table. Of the control group seen since $14,32 \%$ had started to wheeze over the past 14 years, with one subject falling into the severest group (class V). Most subjects at 14 with little or no wheezing (classes A and B) still had minimal symptoms at 28 , with $73 \%$ of these two groups being in classes $S$ and $\mathrm{T}$. Those with frequent wheezing at 14 (classes $C$ and $\mathrm{D}$ ) remained symptomatic, with $69 \%$ ending in the equivalent groups at 28 years, classes $\mathrm{U}$ and $\mathrm{V}$.

The classes at 21 and 28 could be directly compared and the groups be further classified according to the change in grade from 21 to 28 years-that is, worse, the same, or improved. The 21 year old classes of the subjects still being seen and their change in class at 28 years are shown in table VIII. Most subjects in classes $W$ and $Z$ remained in the equivalent groups at 28 years. Some subjects who had wheezed infrequently in the previous 12 months when seen at 21 did show some tendency for a worsening of their asthma by $28,44 \%$ moving to a more severe grade. Overall $154(50 \%)$ of the asthmatics stayed in the equivalent group, $79(26 \%)$ worsened, and $73(24 \%)$ improved. 


\section{Discussion}

The results reported here confirm and extend the findings of the previous reviews of these subjects. At the age of 21 about half the subjects who had had minor wheeze in childhood had stopped wheezing, and in most of the remainder wheeze continued to be trivial. Only a quarter of those with frequent episodes of asthma over a number of years in childhood were wheeze free at 21 . Ninety five per cent of those with persistent asthma in childhood continued to have asthma at 21 , and in the majority this continued to be persistent.

Between 21 and 28 years there were no substantial changes in the pattern of asthma. About equal numbers of subjects improved and became worse. About a third of those who had persistent asthma at 21 improved, but this was matched by deterioration in about $40 \%$ of those with frequent episodes of asthma at 21 .
Of particular interest was the recurrence of wheeze in $31 \%$ of those who were wheeze free at 21 ; many of these subjects had only trivial wheeze during childhood and would probably not be able to recall this. They could well be labelled "adult onset asthma." The development of wheeze in some control subjects who were selected at 7 with no history of wheeze was of concern but difficult to interpret because of the small numbers.

In the early phases of this study Williams and $\mathrm{McNicol}^{17}$ showed that wheezy bronchitis and asthma were different labels for the same disease. They found that the frequency of wheezing correlated well with severity and prognosis. ${ }^{7}$ At the 1978 review Martin et al ${ }^{10}$ found a similar relation between wheezing frequency, disease severity, airway reactivity, and prognosis. In this group at all stages, therefore, asthma has been defined as the presence of any wheezing, with the frequency of that wheezing being a measure of the severity of the illness. The advantage of such a general definition is that it

TABLE V—Spirometry values

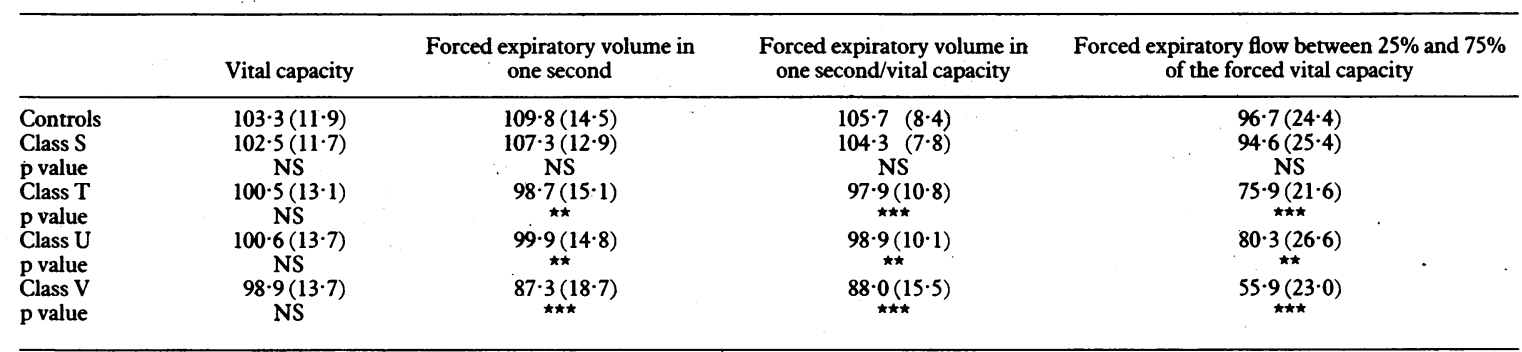

Figures represent mean (SD) percentage predicted. Analysis was performed by the $t$ test with pooled variance estimates. NS $=$ not significant; ${ }^{\star}=\mathrm{p}<0 \cdot 05$; $\star \star=\mathrm{p}<0.01 ;{ }^{\star \star \star}=\mathrm{p}<0.001$.

TABLE VI-Current smoking habits. Figures represent numbers of subjects (percentage in parentheses)

\begin{tabular}{lcccc}
\hline & Non-smoker & $\begin{array}{c}<20 \\
\text { Cigarettes/day }\end{array}$ & $\begin{array}{c}\geqslant 20 \\
\text { Cigarettes/day }\end{array}$ & $\begin{array}{c}\text { Total number } \\
\text { of subjects in group }\end{array}$ \\
\hline Controls & $32(67)$ & $10(21)$ & $6(12)$ & 48 \\
Class S & $70(67)$ & $21(20)$ & $14(13)$ & 105 \\
Class T & $36(54)$ & $18(27)$ & $13(19)$ & 67 \\
Class U & $41(58)$ & $18(25)$ & $12(17)$ & 71 \\
Class V & $47(59)$ & $20(25)$ & $13(16)$ & 80 \\
\hline \multicolumn{1}{c}{ Total } & $226(61)$ & $87(23)$ & $58(16)$ & 371
\end{tabular}

TABLE VII-Outcome of subjects seen at 14 years of age. Figures represent numbers from each 14 year old group who were seen at 28 (percentage in parentheses)

\begin{tabular}{|c|c|c|c|c|c|c|}
\hline & \multirow{2}{*}{$\begin{array}{l}\text { No in } 14 \text { year } \\
\text { classes seen } \\
\text { at } 28 \text { years }\end{array}$} & \multirow[b]{2}{*}{ Control } & \multicolumn{4}{|c|}{28 Year classes } \\
\hline & & & $S$ & $\mathbf{T}$ & $\mathrm{U}$ & $\mathbf{V}$ \\
\hline \multicolumn{7}{|l|}{14 Year classes: } \\
\hline Control & 69 & $47(68)$ & $9(13)$ & $6(9)$ & $6(9)$ & $1(1)$ \\
\hline Class A & 50 & & $26(52)$ & $12(24)$ & $11(22)$ & 1 (2) \\
\hline Class B & 74 & & $41(55)$ & $11(15)$ & $14(19)$ & $8(11)$ \\
\hline Class C & 77 & & $12(16)$ & $17(22)$ & $23(30)$ & $25(32)$ \\
\hline Class D & 47 & & $1(2)$ & $9(19)$ & $5(11)$ & $32(68)$ \\
\hline Not seen at 14 & 45 & & $14(32)$ & $11(24)$ & $11(24)$ & $9(20)$ \\
\hline
\end{tabular}

TABLE VIII-Outcome of subjects seen at 21 and 28 years. Figures represent numbers of each group (with percentages in parentheses)

\begin{tabular}{lcccc}
\hline & \multicolumn{3}{c}{ Change in class from 21 to 28 years } & \\
\cline { 2 - 4 } & Worse & Same & Improved & Total \\
\hline Control & $8(15)$ & $47(85)$ & - & 55 \\
Class W & $31(31)$ & $69(69)$ & - & 100 \\
Class X & $27(44)$ & $16(26)$ & $19(31)$ & 62 \\
Class Y & $21(27)$ & $25(32)$ & $33(41)$ & 79 \\
Class Z & - & $44(67)$ & $22(33)$ & 66 \\
& & & & \\
\hline
\end{tabular}

minimises the underrepresentation of subjects with milder asthma that may occur with more specific criteria.

A major problem with epidemiological studies of asthma is the different definitions used for the disease, ours being no exception. For example, the early studies of Rackemann and Edwards, ${ }^{18}$ Bullen, ${ }^{19}$ Ogilvie, ${ }^{20}$ and Buffum and Settipane ${ }^{21}$ were retrospective studies of subjects diagnosed in hospital clinics or by one of the workers in each group. Schacter et al asked their subjects whether they had ever had asthma or, separately, wheezing. ${ }^{6}$ The more recent studies of Dodge and Burrows, ${ }^{22}$ Broder $e t a l,{ }^{5}$ and Peat $e t a l^{23}$ have all required the previous diagnosis of asthma by a medical practitioner. Some have not defined the disease at all. ${ }^{124}$ All these studies have probably underestimated the prevalence of asthma for a number of reasons. Retrospective studies are bedevilled by problems of subject memory while groups from medical practices tend to represent the more severe cases. The work of Speight $e t$ als and Marks and Hillier ${ }^{26}$ would suggest that subjects with mild asthma may not be recognised by their local medical practitioner or seek medical help and, hence, may not be included in studies that require this diagnosis. We believe the major value of long term follow up studies of asthma, such as the one reported here, is in delineating the course of the disease rather than giving absolute values to the prevalence of the asthma in a particular community.

Our data suggest that the use of wheezing frequency remains a useful measure of the severity of asthma as evidence of increased airways obstruction is more apparent in the more severe groups. None of the features examined separated those in class $S$ from the control group. The presence of hay fever was progressively more common in those with asthma, but only class $\mathrm{V}$ had significantly more eczema than the controls. Abnormalities on physical examination were present particularly in groups $U$ and $V$. The cardinal signs of airways obstruction, expiratory wheeze, and a hyperexpanded chest were found in significant proportions in class $\mathrm{V}$ only. It is clear from the proportions of the total group with abnormalities on examination that they are appreciably different from the average hospital clinic population.

The progress of the group as a whole can be accurately assessed from 21 to 28 because the same severity classification was used at 
both ages. The classes defined at 14 used different criteria but can be approximated to the present grades. Of the 14 year old group as a whole $32 \%$ had been wheeze free for at least three years when seen at 28 years with $27 \%$ of the group continuing to wheeze at least once a week. A further $41 \%$ complained of less frequent wheezing. Recurrence of wheezing had occurred in $27 \%$ of those with minimal symptoms at 14 . These figures are in broad agreement with some earlier studies; of the prospective studies, Johnstone ${ }^{1}$ found that $25 \%$ of his group had ceased wheezing, while Blair ${ }^{2}$ in a larger study reported that $28 \%$ had had no asthma for more than two years before the review. He also stated that $48 \%$ had continued to have chronic asthma but this may have reflected an initial bias in selection. A number of retrospective studies of sufficient length have been reported. Rackemann and Edwards ${ }^{18}$ found that $31 \%$ of their subjects reported being "cured," while 10.9\% still suffered "severe" asthma. Buffum and Settipane, however, who studied a group of private patients, found that $41 \%$ were wheeze free after 10 years and $55 \%$ after $20 .{ }^{21}$ Similar remission rates were found by Barr and $\operatorname{Logan}^{27}$ and Ogilvie. ${ }^{20}$ These studies relied on questionnaires to obtain their data, and there was no interview, examination, or lung function testing for objective evidence of airways obstruction.

Contrary to the findings at 21 years of age, significantly more men than women $(28 \% v 19 \%)$ suffered a worsening of their asthma, reversing the trend for the sexes to be more evenly distributed in the most severe group. Other studies that have followed subjects into adulthood have found either no sex difference in prognosis ${ }^{2324}$ or that women tended to wheeze more than men. ${ }^{27}$

The symptomatic groups were still undertreated by the criteria of Martin et al. ${ }^{11}$ Only in the most severe group had there been any improvement in the numbers deemed to be adequately treated. These findings are of concern as it is possible that the degree of fixed airways obstruction may be altered over time with adequate bronchodilatation. ${ }^{28}$ Of concern also was that many of the subjects with asthma continued to smoke. In the two most severe groups $42 \%$ and $41 \%$ respectively were smoking, with potentially important effects on their airway reactivity and small airway function.

In summary, we have presented data on a group of subjects who had asthma in childhood and who had been followed from the ages of 7 to 28 years with a $77 \%$ recall rate. We have classified our group according to their frequency of wheezing and found that this classification correlated with the presence of other features of the disease. The prognosis for those with frequent wheezing in early adolescence is poor, with most still in the most severe group at 28 years. There is evidence that wheezing recurs in early adult life, suggesting that the prognosis for those with mild asthma may not be as favourable as popularly thought.
We thank Joan Raven and Anna Lanigan for their technical help.

\section{References}

1 Johnstone DE. A study on the natural history of bronchial asthma in children. Am $\mathcal{J}$ Dis Child 1968;115:213-6.

2 Blair H. Natural history of childhood asthma: 20 year followup. Arch Dis Child 1977;52:613-9.

3 Pearson RSB. Asthma, allergy and prognosis. Proceedings of the Royal Society of Medicine 1967;61:467-70.

4 Beck GJ, Doyle CA, Schacter EN. A longitudinal study of respiratory health in a rural community. Am Reo Respir Dis 1982;125:375-81.

5 Broder I, Higgins MW, Matthews KP, Keller JB. Epidemiology of asthma and allergic rhinitis in otal community, Tecumseh, Michigan: IV natural history. f Allergy Clin Immunol 1974;54 $100-10$.

6 Schacter EN, Doyle CA, Beck GJ. A prospective study of asthma in a rural community. Chest 1984;85:623-30.

7 McNicol KN, Williams HE. Spectrum of asthma in childhood-I, clinical and physiological components. Br Med f 1973;iv:7-11.

8 McNicol KN, Williams HE. Spectrum of asthma in childhood-II, allergic components. BrMed f 1973;iv:12-6.

$9 \mathrm{McNicol} \mathrm{KN}$, Williams HE. Spectrum of asthma in childhood-III, psychological and socia components. BrMed $\mathcal{F} 1973$;iv:16-20.

10 Martin AJ, McLennan LA, Landau LI, Phelan PD. The natural history of childhood asthma to dult life. BrMed F 1980;280:1397-400.

11 Martin AJ, Landau LI, Phelan PD. Asthma from childhood at age 21: the patient and his disease. BrMed f 1982;284:380-2.

12 Martin AJ, Landau LI, Phelan PD. Predicting the course of asthma in children. Aust Paediatr $f$ 1982;18:84-7.

13 Martin AJ, Landau LI, Phelan PD. Lung function in young adults who had asthma in childhood. Am Rev Respir Dis 1980;122:609-16.

14 Martin AJ, Landau LI, Phelan PD. Natural history of allergy in asthmatic children followed to adult life. Med J Aust 1981;ii:470-4.

15 Goldman HI, Becklake MR. Respiratory function tests. Am Rev Respir Dis 1959;79:457-66.

16 Ferris BG, Anderson DO, Zickmantel R. Prediction values for screening tests of pulmonary function. Am Rev Respir Dis 1965;91:252-61.

17 Williams HE, McNicol KN. Prevalence, natural history and relationship of wheezy bronchitis and asthma in children: an epidemiological study. $\mathrm{Br} M e d \mathcal{J} 1969$;iv:321.

18 Rackemann FM, Edwards MC. Asthma in children. A follow up study of 688 patients after an interval of 20 years. $N$ Engl I Med 1952;246:815-23.

19 Bullen RS. Some observations on the natural history of asthma in childhood. NY State $\mathcal{J}$ Med 1929;29:545-9.

20 Orivie AG. Asthma: a study in prognosis of 1000 patients. Thorax 1962;17:183-9.

21 Buffum WF, Settipane GA. Prognosis of asthma in childhood. Am $\mathcal{F}$ Dis Child 1966;112:214-7.

22 Dodge RR, Burrows B. The prevalence and incidence of asthma-like symptoms in a genera population sample. Am Rev Respir Dis 1980;122:567-75.

23 Peat JK, Woolcock AJ, Leeder SR, Blackburn CRB. Asthma and bronchitis in Sydney schoolchildren. I. Prevalence during a six year study. Am $\mathcal{f}$ Epidemiol 1980;111:721-7.

24 Ungar L. Bronchial asthma: under observation from one to thirteen years. Joumaal of Allerg 1935-6;7:364-71.

25 Speight ANP, Lee DA, Hey EN. Underdiagnosis and undertreatment of asthma in childhood. BrMed F 1983;286:1253-6.

26 Marks BE, Hillier VF. General practitioners' views on asthma in childhood. Br Med $\mathcal{J}$ 1983;287:949-5.

27 Barr LW, Logan GB. Prognosis of children having asthma. Pediatrics 1964;34:856-60.

28 Brown PJ, Greville HW, Finucane KE. Asthma and irreversible airflow obstruction. Thora 1984;39:131-6.

(Accepted 12 February 1987)

\section{SHORT REPORTS}

\section{Lyme arthritis in southern England}

Lyme disease is an infection with the spirochaete Borrelia burgdorferi. Its arthritic and neurological manifestations are often preceded by a characteristic skin eruption, erythema chronicum migrans. The tick vector, most commonly Ixodes ricinus, is widespread in North America and Europe. Joint disease, well recognised in the United States, ${ }^{1}$ has not been reported in the United Kingdom, although cases from East Anglia, ${ }^{2}$ Scotland, and Southampton ${ }^{3}$ have presented with erythema chronicum migrans alone or with neurological manifestations. We report a case of Lyme disease presenting with an asymmetric oligoarthritis after an insect bite.

\section{Case report}

In June 1986 a 55 year old woman noticed an insect bite on the left calf while playing golf near Southampton. Three days later her left ankle became painful and swollen. After a further four days she developed a feverish illness with a sore throat and non-productive cough; she was treated with a seven day course of oral phenoxymethylpenicillin $250 \mathrm{mg}$ four times daily. Generalised joint pains and swelling of both hands occurred two weeks after the bite followed by simila manifestations in one shoulder, the knees, ankles, and forefeet. Morning stiffness, lasting about 30 minutes, was partly relieved by ibuprofen $400 \mathrm{mg}$ thrice daily. She had previously been well with no ocular, bowel, or urogenital symptoms and had not been abroad.

She was admitted because of continuing pain two months after the insect bite. There was a macular area of faint erythema about $5 \mathrm{~cm}$ in diameter on the left calf, active synovitis of the proximal interphalangeal joints and the metacarpophalangeal joints of both hands, and considerable bilateral flexo tenosynovitis. The right temporomandibular joint, right shoulder, and both knees and ankles were affected. Cardiac and neurological examination gave normal findings.

Her haemoglobin concentration was $129 \mathrm{~g} / 1$, the white cell count $7 \cdot 4 \times 10^{9} / \mathrm{l}$, and platelet count $339 \times 10^{9} /$. The erythrocyte sedimentation rate was $35 \mathrm{~mm}$ in the first hour. Concentrations of rheumatoid and antinuclear factors, cryoglobulins, and complement were normal. Serological tests for chlamydia, parvovirus (IgM) intistreptolysin $\mathrm{O}$, Yersinia enterocolitica, and syphilis were negative. $x$ Ray films of the hands and feet showed no erosive changes. A chest radiograph and electrocardiogram were normal. Serum titres of IgG antibodies against $B$ burgdorferi by indirect immunofluorescence were $1 / 512$ and 1/1024 in samples taken three and 10 weeks respectively after the onset of arthritis. (Titres below $1 / 256$ are considered not significant.) 